\title{
Corn Production as Affected by Phosphorus Enhancers, Phosphorus Source and Lime
}

\author{
Christopher J. Dudenhoeffer ${ }^{1}$, Kelly A. Nelson ${ }^{2}$, Peter P. Motavalli ${ }^{1}$, David Dunn ${ }^{3}$, William E. Stevens ${ }^{3}$, Keith W. \\ Goyne $^{1}$, Manjula Nathan ${ }^{4} \&$ Peter Scharf ${ }^{4}$ \\ ${ }^{1}$ Department of Soil, Environmental and Atmospheric Sciences, University of Missouri, Columbia, MO, USA \\ ${ }^{2}$ Division of Plant Sciences, University of Missouri, Novelty, MO, USA \\ ${ }^{3}$ Division of Plant Sciences, University of Missouri, Portageville, MO, USA \\ ${ }^{4}$ Division of Plant Sciences, University of Missouri, Columbia, MO, USA \\ Correspondence: Kelly A. Nelson, University of Missouri, Greenley Research Center, Novelty, MO 63460, USA. \\ Tel: 1-660-739-4410. E-mail: nelsonke@missouri.edu
}

Received: June 11, 2012 Accepted: July 3, 2012 Online Published: August 24, 2012

doi:10.5539/jas.v4n10p137 URL: http://dx.doi.org/10.5539/jas.v4n10p137

\begin{abstract}
Prompted by high cost of fertilizer, farmers are investigating ways to enhance the efficiency of phosphorus (P) fertilizers. This study examined the effects of liming application $\left(0 \mathrm{Mg} \mathrm{ha}^{-1}\right.$ and recommended rate), $\mathrm{P}$ source [non-treated control and a broadcast application of diammonium phosphate (DAP) or triple superphosphate (TSP)], and the presence or absence of two commercial enhanced efficiency P products (Avail ${ }^{\circledR}$ and $\mathrm{P}_{2} \mathrm{O}_{5}-\mathrm{Max}^{\circledR}$ ) on corn (Zea mays L.) production. The study was conducted at Novelty in northeastern Missouri and Portageville in southeastern Missouri. The P enhancers did not affect plant population, silage dry weights, grain moisture, yield, protein, oil, or starch concentrations at either location. At Portageville, $\mathrm{P}$ enhancers did not affect plant N, $\mathrm{P}, \mathrm{K}$ uptake and apparent $\mathrm{P}$ recovery efficiency (APRE). At Novelty, neither $\mathrm{P}$ enhancer paired with DAP increased $\mathrm{P}$ uptake over the non-treated control. TSP treated with Avail ${ }^{\mathbb{R}}$ increased $\mathrm{P}$ uptake $8.6 \mathrm{~kg} \mathrm{ha}{ }^{-1}$ compared to the non-treated control and $7.1 \mathrm{~kg} \mathrm{ha}^{-1}$ compared to $\mathrm{P}_{2} \mathrm{O}_{5}-\mathrm{Max}^{\circledR}$. In 2010 at Novelty, TSP treated with Avail ${ }^{\circledR}$ increased $\mathrm{K}$ uptake $150 \mathrm{~kg} \mathrm{ha}^{-1}$ compared to the non-treated TSP and $100 \mathrm{~kg} \mathrm{ha}^{-1}$ compared to $\mathrm{P}_{2} \mathrm{O}_{5}-\mathrm{Max}^{\circledR}$. At Novelty, plant population was 4,800 plants $^{-1} \mathrm{a}^{-1}$ greater in the non-limed control compared to the recommended rate in 2011, although plant population at Portageville was not affected. At Portageville, the recommended amount of lime increased grain yields $0.77 \mathrm{Mg} \mathrm{ha}^{-1}$, but there was no effect at Novelty. At Novelty, plant $\mathrm{P}$ uptake increased $3.4 \mathrm{~kg} \mathrm{ha}^{-1}$ with the application of lime, but at Portageville there was no effect. Grain yield increased $0.34 \mathrm{Mg} \mathrm{ha}^{-1}$ with TSP compared to the non-treated control.
\end{abstract}

Keywords: diammonium phosphate, enhanced phosphorus efficiency products, fertilizer source, phosphorus recovery, triple superphosphate

\section{Introduction}

With high fertilizer costs, farmers want to reduce phosphorus $(\mathrm{P})$ application rates and improve crop $\mathrm{P}$ uptake using P enhancers. The manufacturers of Avail ${ }^{\circledR}$ (Specialty Fertilizer Products, Leawood, KS) and $\mathrm{P}_{2} \mathrm{O}_{5}-\mathrm{Max}^{\circledR}$ (P-Max, Rosen's Inc., Fairmont, MN) claimed that their products enhance the efficiency of P-based fertilizers on several soil types. Avail ${ }^{\circledR}$ is a $\mathrm{P}$ enhancer for granular phosphate fertilizers, such as diammonium phosophate (DAP) and monoammonium phosphate (MAP), as well as other liquid phosphate fertilizers. It was designed to reduce the impact of cations (i.e., $\mathrm{Ca}, \mathrm{Fe}, \mathrm{Mn}$, and $\mathrm{Al}$ ) in the soil around the fertilizer granule on soil $\mathrm{P}$ sorption and plant $\mathrm{P}$ uptake. This product reportedly binds with $\mathrm{Ca}, \mathrm{Fe}, \mathrm{Mn}$, and $\mathrm{Al}$ to prevent precipitation of $\mathrm{P}$-bearing minerals (SFP, 2009). The active ingredient in Avail ${ }^{\circledR}$ is a maleic-itaconic copolymer (SFP, 2005). $\mathrm{P}_{2} \mathrm{O}_{5}-\mathrm{Max}^{\circledR}$ is designed to increase $\mathrm{P}$ uptake and improve root surface area resulting in better nutrient absorption and higher yields. The active ingredient is a poly amino acid (L-aspartic acid), sodium salt (Rosen's Inc, 2012).

Few published studies report the effects of Avail ${ }^{\circledR}$ on plant growth and yields. A study conducted at five locations throughout Kansas evaluated the effectiveness of Avail ${ }^{\circledR}$ under corn and wheat cropping systems (Ward, 2010). Avail ${ }^{\mathbb{B}}$ showed no significant effect on plant biomass, $\mathrm{P}$ uptake, or grain yields for corn and wheat. In Canada, two trials evaluated four rates of seed-placed MAP at $0,6.5,13$, and $19.5 \mathrm{~kg} \mathrm{P}^{-1}{ }^{-1}$ with and without Avail ${ }^{\circledR}$ (Karamanos \& Puurveen, 2011). The results showed neither a significant effect of treating MAP with Avail ${ }^{\mathbb{B}}$, nor a significant interaction between Avail $^{\mathbb{B}}$ treatment and rate of $\mathrm{P}$ application on wheat yield and $\mathrm{P}$ uptake. 
Many sources of $\mathrm{P}$ fertilizers are available on the market, and the three most popular fertilizers used by farmers are triple superphosphate (TSP), MAP, and DAP. Differences among these fertilizers include their solubility and nutrient concentrations. In alkaline soil, monocalcium phosphate (main P form in TSP) is more soluble and available to plants than DAP, but it is slightly less soluble in acidic soil (Bouldin \& Sample, 1959). Producers prefer using MAP and DAP because co-application of $\mathrm{P}$ and nitrogen $(\mathrm{N})$ potentially reduces application time and cost. A greenhouse study using corn evaluated DAP's effectiveness as a dual source of N and P. DAP was compared to urea plus single superphosphate (SSP) placed at different soil depths (surface broadcast, incorporation, and deep banding) in a calcareous clay soil. Regardless of fertilizer placement, soil treated with urea plus SSP had higher Olsen P than soil treated with DAP. For both fertilizers, surface broadcasting apparently reduced the accessibility of $\mathrm{P}$ to the plant roots and resulted in a lower $\mathrm{P}$ uptake and plant yield than incorporation treatments. When the fertilizers were either incorporated or deep-placed, $\mathrm{N}$ uptake was as high with DAP as with urea plus SSP. However, surface application resulted in less N uptake from DAP than from urea plus SSP. Urea plus SSP produced greater plant yields than those obtained with DAP regardless of fertilizer placement ( $\mathrm{Lu}$, Chien, Henao, \& Sompongse, 1987). Other research has shown little to no difference in grain yields and soil P levels between P fertilizer sources (Reid, Winward, \& Koenig, 2004).

Calcium deficiency (Ritchey, Silva, \& Costa, 1982) and Al toxicity (Pavan, Binghamm, \& Pratt, 1982) are major yield limiting factors in acid soils. Liming resolves these issues by increasing soil $\mathrm{pH}$ and $\mathrm{Ca}$. Applying lime increases exchangeable $\mathrm{Ca}$, exchangeable $\mathrm{Mg}$, and decreases exchangeable $\mathrm{Al}$ (Lim \& Shen, 1978). Moschler, Martens, Rich, \& Shear (1973) evaluated how liming affected exchangeable Ca and exchangeable Al in the upper $10 \mathrm{~cm}$ of soil in no-tilled (NT) and conventional tilled (CT) corn in Virginia. In limed NT soil, exchangeable Al comprised only $0.2 \%$ of the exchangeable cations, compared to $29.9 \%$ in non-limed NT soil. Aluminum saturation in CT soil with lime was $0.8 \%$ compared to $14.0 \%$ in non-limed, CT soil. More exchangeable $\mathrm{Ca}$ and greater soil $\mathrm{pH}$ were present in the limed NT soil compared to limed CT soil. Greater exchangeable $\mathrm{Al}$ and a less favorable rooting environment in the nonlimed soils reduced early growth of corn, and increased corn maturity at harvest with limed soil increased corn yields.

A surface application of lime in NT increased soil pH, exchangeable $\mathrm{Ca}$, and decreased exchangeable $\mathrm{Al}$, which increased corn yields between 718 to $828 \mathrm{~kg} \mathrm{ha}^{-1}$ (Blevins, Murdock, \& Thomas, 1978). However, the method of applying lime also determines lime effectiveness. Moschler et al. (1973) compared continuous NT corn to continuous CT corn with or without lime. In NT corn, lime was applied to the surface, while in CT corn the lime was incorporated into the soil. Lime application increased corn grain yield more than twice as much in NT as in CT. In both tillage systems, lime was essential for increasing yields. Other research has shown no effect of lime or a decrease in grain yields in some instances (Estes, 1972; Woodruff, Moore, \& Musen, 1987). In central Iowa, only one of five site-years increased grain yield $\left(230 \mathrm{~kg} \mathrm{ha}^{-1}\right)$ in response to a lime application. The low response likely was due to the presence of high-pH (calcareous) subsoils (Bianchini \& Mallarino, 2002). Caires, Alleoni, Cambri, \& Barth (2005) also found limited results from applying lime in Brazil. With soybean, only one site-year of eight and only one site-year out of two for wheat showed increased grain yields.

Increased fertilizer costs, new P enhancer products, and challenges of corn production with NT prompted this investigation of ways to enhance the effectiveness of P fertilizers. The objective of this study was to evaluate the effect of liming, $\mathrm{P}$ source, and $\mathrm{P}$ enhancer products on corn production and $\mathrm{P}$ uptake.

\section{Materials and Methods}

\subsection{Husbandry of the Experimental Site}

Research trials were established at the Greenley Memorial Research Center $\left(40^{\circ} 01^{\prime} \mathrm{N}, 92^{\circ} 11^{\prime} \mathrm{W}\right)$ near Novelty, Mo., on a Putnam silt loam (fine, smectitic, mesic Vertic Albaqualfs) in 2010 and 2011, and the Delta Center $\left(36^{\circ} 23^{\prime} \mathrm{N}, 89^{\circ} 36^{\prime} \mathrm{W}\right)$ near Portageville, Mo., on a Tiptonville silt loam (fine-silty, mixed, superactive, thermic Oxyaquic Argiudolls) in 2010. Each site was arranged as a factorial randomized complete block design with four replications.

Treatments included a three-factor arrangement of $\mathrm{P}$ source (non-treated control and a broadcast application of DAP or TSP), presence or absence of the phosphorus efficiency products (non-treated control, Avail ${ }^{\circledR}$ at $2.1 \mathrm{~L}$ $\mathrm{Mg}^{-1}$, and $\mathrm{P}_{2} \mathrm{O}_{5}-\mathrm{Max}^{\circledR}$ at $\left.4.2 \mathrm{~L} \mathrm{Mg}^{-1}\right)$ and broadcast surface application of agriculture calcitic limestone $(0$ and recommended i.e. $8.1 \mathrm{Mg} \mathrm{ha}^{-1}$ at Novelty in $2010,3.4 \mathrm{Mg} \mathrm{ha}^{-1}$ at Novelty in 2011 , and $4.5 \mathrm{Mg} \mathrm{ha}^{-1}$ at Portageville in 2010) based on University of Missouri lime recommendations (Buchholz, 1992). Plots were 3 by $14 \mathrm{~m}$. The Novelty site was no-till and rain fed, while the Portageville site was conventionally tilled and furrow irrigated ( $25 \mathrm{~mm}$ of irrigation water was applied when no rainfall events occurred). Management information is available in Table 2. 


\subsection{Soil Sampling and Chemical Analysis}

Initial soil samples were collected from each replication to a $15 \mathrm{~cm}$ depth using a stainless steel push probe. Samples were characterized for soil $\mathrm{pH}\left(0.01 \mathrm{M} \mathrm{CaCl}_{2}\right)$, Bray-1 P, exchangeable $\left(1 \mathrm{M} \mathrm{NH}_{4} \mathrm{OA}_{\mathrm{C}}\right)$ potassium, calcium, magnesium, zinc (DTPA extraction), soil organic matter (loss-on-ignition), neutralizable acidity (Woodruff buffer), and cation exchange capacity using standard methods at the University of Missouri Soil and Plant Testing Laboratory (Nathan, Stecker, \& Sun, 2006) (Table 1). Corn silage yield was measured by harvesting $1.5 \mathrm{~m}$ of one row at physiological maturity with data expressed on a dry matter basis. The silage samples underwent a $\mathrm{H}_{2} \mathrm{SO}_{4}-\mathrm{H}_{2} \mathrm{O}_{2}$ digestion, followed by total $\mathrm{N}$ (colorimetric Indophenols blue), $\mathrm{P}$ (colorimetric ammonium molybdate), and $\mathrm{K}$ (atomic absorption) analyses. Plant $\mathrm{N}, \mathrm{P}$, and $\mathrm{K}$ uptake were calculated by multiplying silage dry matter yield by tissue nutrient concentration. Apparent phosphorus recovery efficiency (APRE) was calculated as $\left[\left(\left(\mathrm{P} \text { uptake } \text { treated }-\mathrm{P} \text { uptake }_{\text {control }}\right) /(\mathrm{P} \text { fertilizer applied })\right)^{*} 100\right]$.

\subsection{Final Yield Determination}

Corn grain yield and moisture content were measured by harvesting the two center rows with a plot combine (Wintersteiger Delta, Salt Lake City, UT). At Novelty, grain samples were collected from each plot and evaluated for starch, protein, and oil concentration (Foss Infratec, Eden Prairie, MN). Grain yields were adjusted to $155 \mathrm{~g} \mathrm{~kg}^{-1}$ moisture content prior to analysis. All data were analyzed using an analysis of variance, and means were separated using Fisher's Protected LSD $(P=0.1)$. Data were combined over factors and locations when appropriate as indicated by the analysis of variance (data not presented).

Table 1. Soil analysis for the P source, P enhancer, and ag lime experiment at Portageville in 2010 and Novelty in 2010 and 2011

\begin{tabular}{lccc}
\hline & \multicolumn{2}{c}{ Novelty } & Portageville \\
\cline { 2 - 3 } & 2010 & 2011 & 2010 \\
\hline $\mathrm{pH}_{\mathrm{s}}\left(0.01 \mathrm{M} \mathrm{CaCl}_{2}\right)$ & $5.4 \pm 0.1^{\dagger}$ & $5.8 \pm 0.1$ & $5.2 \pm 0.3$ \\
Bray-1 P $\left(\mathrm{kg} \mathrm{ha}^{-1}\right)$ & $30 \pm 8$ & $10 \pm 2$ & $118 \pm 30$ \\
Exchangeable $\left(1 \mathrm{M} \mathrm{NH}_{4} \mathrm{OA}_{\mathrm{C}}\right)$ & & & \\
$\quad$ Potassium $\left(\mathrm{kg} \mathrm{ha}^{-1}\right)$ & $285 \pm 27$ & $80 \pm 13$ & $278 \pm 86$ \\
$\quad$ Calcium $\left(\mathrm{kg} \mathrm{ha}^{-1}\right)$ & $5008 \pm 155$ & $3918 \pm 344$ & $1935 \pm 383$ \\
Magnesium $\left(\mathrm{kg} \mathrm{ha}^{-1}\right)$ & $451 \pm 84$ & $325 \pm 33$ & $344 \pm 95$ \\
Zinc $\left(\mathrm{mg} \mathrm{kg}^{-1}\right)$ & $0.78 \pm 0.15$ & $0.35 \pm 0.06$ & $\mathrm{NA}$ \\
Soil organic matter $\left(\mathrm{g} \mathrm{kg}^{-1}\right)$ & $26 \pm 2$ & $22 \pm 1$ & $14 \pm 2$ \\
Neutralizable acidity $\left(\mathrm{cmol}_{\mathrm{c}} \mathrm{kg}^{-1}\right)$ & $4 \pm 0.8$ & $1.9 \pm 0.3$ & $2.9 \pm 0.8$ \\
Cation exchange capacity $\left(\mathrm{cmol}_{\mathrm{c}} \mathrm{kg}^{-1}\right)$ & $17 \pm 1$ & $12 \pm 1$ & $9 \pm 1$ \\
\hline
\end{tabular}

${ }^{\dagger}$ Standard deviation ${ }^{\star} \mathrm{NA}=$ Not available

Table 2. Management information at Portageville in 2010 and Novelty in 2010 and 2011

\begin{tabular}{|c|c|c|c|}
\hline \multirow[b]{2}{*}{ Management information } & \multicolumn{2}{|r|}{ Novelty } & \multirow{2}{*}{$\begin{array}{l}\text { Portageville } \\
2010\end{array}$} \\
\hline & 2010 & 2011 & \\
\hline Previous crop & Corn & Wheat & Corn \\
\hline Hybrid or cultivar & DK 61-69 VT3 & DKC 63-42 VT3 & Cropland Genetics $68-31$ \\
\hline Planting date & 26 May & 10 May & 7 Apr. \\
\hline Seeding rate & 74100 seeds ha ${ }^{-1}$ & 76100 seeds ha ${ }^{-1}$ & 74100 seeds ha ${ }^{-1}$ \\
\hline Tissue harvest date & 7 Sep. & 25 Aug. & 16 Aug. \\
\hline Harvest date & 1 Oct. & 14 Sep. & 8-9 Sep. \\
\hline \multicolumn{4}{|l|}{ Fertilizer } \\
\hline $\mathrm{P}$ application (date \& rate) & 27 Apr. $118 \mathrm{~kg} \mathrm{P}_{2} \mathrm{O}_{5} \mathrm{ha}^{-1}$ & 31 Mar., $112 \mathrm{~kg} \mathrm{P}_{2} \mathrm{O}_{5} \mathrm{ha}^{-1}$ & 6 Apr. $56 \mathrm{~kg} \mathrm{P}_{2} \mathrm{O}_{5} \mathrm{ha}^{-1}$ \\
\hline Lime application (date \& rate) & 1 Apr., $8.1 \mathrm{Mg} \mathrm{ha}^{-1}$ & 29 Mar., $3.4 \mathrm{Mg} \mathrm{ha}^{-1}$ & 1 Apr., $4.5 \mathrm{Mg} \mathrm{ha}^{-1}$ \\
\hline $\begin{array}{l}\text { Additional fertilizer (date, } \\
\text { source, \& rate) }\end{array}$ & $\begin{array}{l}12 \mathrm{Apr} ., \text { Anhydrous ammonia } \\
\qquad\left(263 \mathrm{~kg} \mathrm{~N} \mathrm{ha}^{-1}\right)\end{array}$ & $\begin{array}{l}31 \text { Mar., Anhydrous ammonia (202 kg N } \\
\text { ha }^{-1} \text { ) }\end{array}$ & $\begin{array}{c}7 \text { Apr., Urea }\left(56 \mathrm{~kg} \mathrm{~N} \mathrm{ha}^{-1}\right)+\mathrm{NBPT}(4 \mathrm{~L} \\
\left.\mathrm{Mg}^{-1}\right)\end{array}$ \\
\hline Sidedress N (date \& rate) & $\begin{array}{c}11 \text { June, } 32 \% \text { UAN (168 kg N } \\
\left.\text { ha }^{-1}\right)\end{array}$ & NA & $\begin{array}{c}5 \text { May, Urea }\left(168 \mathrm{~kg} \mathrm{~N} \mathrm{ha}^{-1}\right)+\text { NBPT }(4 \\
\left.\mathrm{L} \mathrm{Mg}^{-1}\right)\end{array}$ \\
\hline \multicolumn{4}{|l|}{ Weed management (date \& rate) } \\
\hline Burndown & $\begin{array}{l}21 \text { Apr., Glyphosate }(0.72 \mathrm{~kg} \\
\left.\text { a.i. } \mathrm{ha}^{-1}\right)\end{array}$ & $\begin{array}{c}11 \text { Apr., Glyphosate }\left(1.06 \mathrm{~kg} \text { a.i. } \mathrm{ha}^{-1}\right)+ \\
\text { DS }\left(0.36 \mathrm{~kg} \mathrm{a.i.} \mathrm{ha} \mathrm{ha}^{-1}\right)+\text { DAS } \\
\left(512 \mathrm{~mL} \mathrm{ha}^{-1}\right)\end{array}$ & $\begin{array}{l}5 \text { Apr., Glyphosate } \\
\left(1.12 \mathrm{~kg} \mathrm{a} \text { i. }^{-1}\right)\end{array}$ \\
\hline Preemergence & $\begin{array}{c}21 \text { Apr., Atrazine }(1.43 \mathrm{~kg} \text { a.i. } \\
\left.\text { ha }^{-1}\right)+ \text { S-metolachlor } \\
\left(1.11 \mathrm{~kg} \mathrm{a}^{-1 .} \mathrm{ha}^{-1}\right)\end{array}$ & $\begin{array}{l}13 \text { Apr., Atrazine }\left(2.17 \mathrm{~kg} \text { a.i. } \mathrm{ha}^{-1}\right)+\mathrm{S}- \\
\text { metolachlor }\left(1.68 \mathrm{~kg} \text { a.i. } \mathrm{ha}^{-1}\right)\end{array}$ & $\begin{array}{l}9 \text { Apr., Atrazine }\left(3.5 \mathrm{~kg} \text { a.i. } \mathrm{ha}^{-1}\right)+\mathrm{S}- \\
\text { metolachlor }\left(1.01 \mathrm{~kg} \mathrm{a.i.} \mathrm{ha}^{-1}\right)\end{array}$ \\
\hline Postemergence & $\begin{array}{l}22 \text { June, Glyphosate } \\
\left(1.06 \mathrm{~kg} \mathrm{a.i.}^{-1}\right)\end{array}$ & NA & $\begin{array}{c}8 \text { May, Atrazine }\left(1.1 \mathrm{~kg} \text { a.i. ha }{ }^{-1}\right)+ \\
\text { Glyphosate } \\
\left(1.5 \mathrm{~kg} \mathrm{a.i.} \mathrm{ha}^{-1}\right)\end{array}$ \\
\hline
\end{tabular}

\footnotetext{
${ }^{\dagger}$ Abbreviations: DAS, Diammonium sulfate; DS, Dimethylamine salt; NA, None applied; UAN, Urea ammonium nitrate.

'Acetochlor (2-chloro-2'-methyl-6'ethyl-N-ethoxymethylacetanilide); atrazine (2-chloro-4-(ethylamino)-6- (isopropylamino) -s-triazine); dimethylamine salt (2,4-Dichlorophenoxyacetic acid); glyphosate (N-(phosphonomethyl)glycine); NBPT (N- (n-butyl) thiophosphoric triamide); S-metolachlor (2-chloro-N-(2-ethyl-6-methylphenyl)-N-[(1S)-2-methoxy-1-methylethyl] acctamide).
} 


\section{Results and Discussion}

The 2010 growing season at Novelty received the highest cumulative precipitation of the three growing seasons (Figure 1). From March 30 to September 27, Novelty's cumulative precipitation was $1082 \mathrm{~mm}$ in 2010 and 559 $\mathrm{mm}$ in 2011, while Portageville received $405 \mathrm{~mm}$ in 2010. In Missouri, the long term (1895-1998) average growing season (April through September) cumulative precipitation was $612 \mathrm{~mm}$ (Hu \& Buyanovsky, 2003). Although environmental differences occurred among years, no 4-way interactions (year*liming*P source*P enhancer) existed for the parameters evaluated; thus, main effects are reported and interactions presented when appropriate.
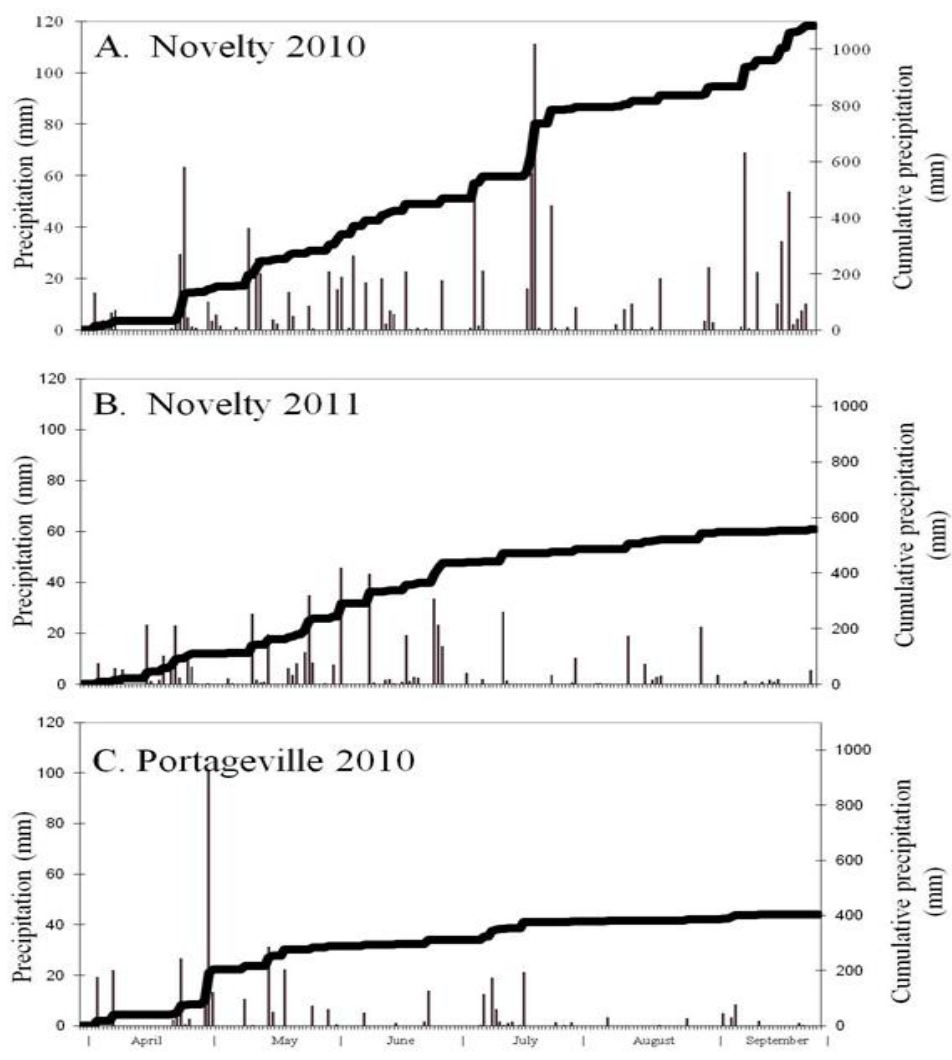

Figure 1. Daily (bars) and cumulative (line) precipitation from March through September of 2010 and 2011 at Novelty (A and B) and 2010 at Portageville (C), Mo

\subsection{Phosphorus Enhancer}

Enhanced efficiency $\mathrm{P}$ products did not affect plant population $(P=0.31)$, silage dry weights $(P=0.48)$, grain moisture $(P=0.69)$, yield $(P=0.65)$, grain oil $(P=0.44)$, protein $(P=0.97)$, or starch $(P=0.48)$ concentration compared to the non-treated control (data not presented). Phosphorus source and $\mathrm{P}$ enhancer affected plant $\mathrm{P}$ uptake at Novelty, but not at Portageville (Table 3). When the fertilizer was not treated with a P enhancer, DAP increased plant $\mathrm{P}$ uptake 8.2 to $8.9 \mathrm{~kg} \mathrm{ha}^{-1}$ greater than the non-treated control and TSP. Neither of the P enhancers combined with DAP increased P uptake over the non-treated control. Triple superphosphate treated with Avail ${ }^{\circledR}$ increased $\mathrm{P}$ uptake $8.6 \mathrm{~kg} \mathrm{ha}^{-1}$ compared to non-treated TSP and $7.1 \mathrm{~kg} \mathrm{ha}^{-1}$ compared to $\mathrm{P}_{2} \mathrm{O}_{5}-\mathrm{Max}^{\circledR}$. The lack of response in $\mathrm{P}$ uptake at Portageville may have resulted from greater Bray 1-P levels $\left(118 \mathrm{~kg} \mathrm{ha}^{-1}\right)$ as compared to Novelty $\left(10\right.$ to $\left.30 \mathrm{~kg} \mathrm{ha}^{-1}\right)$ (Table 1). The differences in P uptake between TSP and DAP applied with Avail ${ }^{\circledR}$ could result from differences in fertilizer solubility. Monocalcium phosphate, the main $\mathrm{P}$ form in TSP, is more available to plants and more soluble than DAP in alkaline soil, but less soluble in acidic soil (Bouldin \& Sample, 1959). The soils in this experiment were slightly acidic (pH 5.4 to 5.8), thus TSP was likely less soluble than DAP at our study sites (Table 1). Therefore, a greater proportion of P from TSP was likely retained in the zone of protection provided by Avail ${ }^{\circledR}$ resulting, subsequently, in the greater P uptake.

Plant K uptake was not affected by P enhancers at Portageville or the 2011 growing season at Novelty (Table 3). Data from the 2010 growing season at Novelty showed an interaction between P source and P enhancer for K uptake. TSP treated with Avail ${ }^{\circledR}$ increased K uptake over all other P source-P enhancer combinations except 
$\mathrm{P}_{2} \mathrm{O}_{5}-\mathrm{Max}^{\circledR}$ applied with the non-treated P-source. When TSP was the $\mathrm{P}$ source, Avail ${ }^{\circledR}$ increased $\mathrm{K}$ uptake 151.1 $\mathrm{kg} \mathrm{ha}^{-1}$ compared to the non-treated TSP and $99.9 \mathrm{~kg} \mathrm{ha}^{-1}$ compared to $\mathrm{P}_{2} \mathrm{O}_{5}-\mathrm{Max}^{\circledR}$. The non-treated P source had higher plant K uptake $75.7 \mathrm{~kg} \mathrm{ha}^{-1}$ than TSP when no $\mathrm{P}$ enhancer was applied. However, there was no effect of $\mathrm{P}$ enhancer on $\mathrm{N}$ uptake $(P=0.45)$ or APRE $(P=0.43)$ (data not presented). Ward (2010) found similar results with Avail $^{\circledR}$ in Kansas for corn and wheat. There was no significant effect of Avail ${ }^{\circledR}$ on biomass production, tissue $\mathrm{P}$ concentration, or grain yields (data not presented). Similarly, in Canada, Karamanos and Puurveen (2011) showed neither a significant effect of treating MAP with Avail ${ }^{\circledR}$, nor a significant interaction between Avail ${ }^{\circledR}$ treatment and rate of $\mathrm{P}$ on wheat yield and $\mathrm{P}$ uptake.

Table 3. Phosphorus and K uptake results based on P enhancers. Data were combined over 2010 and 2011 at Novelty, and at Portageville in 2010, liming rate, and P source

\begin{tabular}{|c|c|c|c|c|c|c|c|c|c|}
\hline \multirow[b]{5}{*}{ P enhancer } & & & & & \multicolumn{5}{|c|}{ K uptake } \\
\hline & \multicolumn{4}{|c|}{ P uptake } & \multicolumn{4}{|c|}{ Novelty } & \multirow[b]{4}{*}{ Portageville } \\
\hline & \multicolumn{3}{|c|}{ Novelty } & \multirow[b]{3}{*}{ Portageville } & \multicolumn{3}{|c|}{2010} & \multirow[b]{3}{*}{2011} & \\
\hline & \multicolumn{3}{|c|}{ P source } & & \multicolumn{2}{|c|}{ P source } & \multirow[b]{2}{*}{$\mathrm{TSP}^{\dagger}$} & & \\
\hline & Non-treated & $\mathrm{DAP}^{\dagger}$ & $\mathrm{TSP}^{\dagger}$ & & Non-treated & DAP $^{\dagger}$ & & & \\
\hline & \multicolumn{4}{|c|}{ 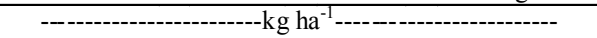 } & \multicolumn{5}{|c|}{ 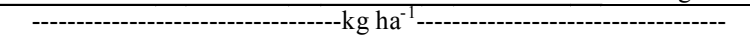 } \\
\hline Non-treated & 32.1 & 40.3 & 31.4 & 53.1 & 289.6 & 283.7 & 213.9 & 303.2 & 278.0 \\
\hline Avail $^{(B)}$ & 29.2 & 36.8 & 40.0 & 47.1 & 220.6 & 269.9 & 365.0 & 320.8 & 271.9 \\
\hline $\mathrm{P}_{2} \mathrm{O}_{5}-\mathrm{Max}^{\circledR}$ & 35.3 & 32.5 & 32.9 & 49.4 & 292.0 & 256.4 & 265.1 & 333.3 & 257.2 \\
\hline $\operatorname{LSD}(\mathrm{P}=0.1)$ & \multicolumn{3}{|c|}{ - } & $\mathrm{NS}^{\S}$ & \multicolumn{3}{|c|}{ - } & NS & NS \\
\hline $\mathrm{P}$-value & \multicolumn{3}{|c|}{--------------0.033 ---------------- } & 0.365 & \multicolumn{3}{|c|}{---------------0.010----------------- } & 0.438 & 0.563 \\
\hline
\end{tabular}

${ }^{\dagger}$ DAP and TSP was applied at a $117 \mathrm{~kg} \mathrm{P}_{2} \mathrm{O}_{5} \mathrm{ha}^{-1}$ at Novelty in 2010, $112 \mathrm{~kg} \mathrm{P}_{2} \mathrm{O}_{5}$ ha $^{-1}$ at Novelty in 2011, and $56 \mathrm{~kg} \mathrm{P}_{2} \mathrm{O}_{5}$ ha $^{-1}$ at Portageville in 2010.

"Data were combined over years (2010 and 2011).

${ }^{\S} \mathrm{NS}=$ Not significant

\subsection{Liming Application}

Grain moisture, oil, protein, and starch concentrations were not affected by the lime treatment at either location (data not presented). At Novelty, the plant population was 4800 plants ha $^{-1}$ greater in the non-limed control compared to the recommended lime rate in 2011, while at Portageville plant population was not affected (Table 4). Applying the recommended amount of lime increased grain yields $0.77 \mathrm{Mg} \mathrm{ha}^{-1}$ at Portageville, but not at Novelty. Blevins et al. (1978) found that surface application of lime on NT increased corn yields between 718 to $828 \mathrm{~kg} \mathrm{ha}^{-1}$ because of the subsequent increase in soil $\mathrm{pH}$, exchangeable $\mathrm{Ca}$, and decreased exchangeable $\mathrm{Al}$.

Table 4. Plant population, yield, $\mathrm{P}$ uptake, and apparent $\mathrm{P}$ recovery efficiency (APRE) results as affected by recommended lime rate. Data were combined over 2010 and 2011 at Novelty, and at Portageville in 2010 except for yield, plant population, and P uptake

\begin{tabular}{|c|c|c|c|c|c|c|c|c|}
\hline \multirow[b]{3}{*}{ Liming Rate } & \multicolumn{3}{|c|}{ Plant population } & \multirow{2}{*}{\multicolumn{2}{|c|}{ Yield }} & \multirow{2}{*}{\multicolumn{2}{|c|}{ P uptake }} & \multirow[b]{3}{*}{ APRE } \\
\hline & \multicolumn{2}{|c|}{ Novelty } & \multirow[b]{2}{*}{ Portageville } & & & & & \\
\hline & 2010 & 2011 & & Novelty & Portageville & Novelty & Portageville & \\
\hline & ----- & ----plan & - & ----1 & $\mathrm{~g} \mathrm{ha}^{-1}-{ }^{----}$ & - & $a^{-1}----\cdot---$ & $\%$ \\
\hline None & 59700 & 58100 & 37600 & 10.15 & 7.07 & 32.8 & 50.5 & 7.2 \\
\hline Recommended $^{\dagger}$ & 64500 & 55600 & 35400 & 9.78 & 7.84 & 36.2 & 49.2 & -6.2 \\
\hline $\operatorname{LSD}(P=0.1)$ & $\mathrm{NS}^{\S}$ & 2000 & NS & NS & 0.20 & 3.1 & NS & 13.0 \\
\hline
\end{tabular}

${ }^{\dagger}$ The recommended liming rate was $8.1 \mathrm{Mg} \mathrm{ha}^{-1}$ at Novelty $2010,3.4 \mathrm{Mg} \mathrm{ha}^{-1}$ at Novelty 2011 , and $4.5 \mathrm{Mg} \mathrm{ha}^{-1}$ at Portageville 2010.

${ }^{\ddagger}$ Data were combined over years (2010 and 2011).

${ }^{\S} \mathrm{NS}=$ Not significant.

Lime application had no effect on $\mathrm{N}$ and $\mathrm{K}$ uptake. At Novelty, phosphorus uptake increased $3.4 \mathrm{~kg} \mathrm{P} \mathrm{ha-1}{ }^{-1}$ with the application of lime, but at Portageville there was no effect (Table 4). Portageville's lack of P-uptake differences might be due to greater Bray 1-P soil levels $\left(118 \mathrm{~kg} \mathrm{ha}^{-1}\right)$ compared to Novelty (10 to $\left.30 \mathrm{~kg} \mathrm{ha}^{-1}\right)$ (Table 1). The increased $\mathrm{P}$ uptake with application of lime could be due to adsorption-desorption and precipitation reactions in the soil (Barrow, 1984). These reactions are influenced by increased $\mathrm{pH}$ and $\mathrm{Ca}$ concentrations resulting from lime application (Barrow, 1984). This increases $\mathrm{P}$ available to plants in the soil solution. However, the lime application in this research decreased APRE $13.4 \%$. 


\subsection{Phosphorus Source}

Silage dry weights increased $2.2 \mathrm{Mg} \mathrm{ha}^{-1}$ with an application of lime in the non-treated control, but no dry weight differences between lime treatments were observed in the presence of DAP or TSP (Table 5). Triple superphosphate increased silage dry weights $2.0 \mathrm{Mg} \mathrm{ha}^{-1}$ over the non-treated control when no lime was applied. With application of TSP or DAP, grain moisture was 9 to $13 \mathrm{~g} \mathrm{~kg}^{-1}$ lower than the non-treated control. Grain yield increased $0.34 \mathrm{Mg} \mathrm{ha}^{-1}$ with TSP compared to the non-treated control. However, P source did not affect N uptake, grain oil, protein, starch and APRE (data not presented). Other research has shown little to no difference in grain yields and soil P levels between P fertilizer sources (Reid et al., 2004). Garcia et al. (1997) tested P availability of several P fertilizers in calcareous soils with a greater P sorption capacity. Available P levels did not increase with application of single superphosphate, TSP, or DAP. This was possibly due to the sorption of $\mathrm{P}$ by the formation of $\mathrm{Ca}$ phosphates in these high $\mathrm{pH}$ and $\mathrm{Ca}$ content soils.

Table 5. P source effects on silage dry weights, grain moisture, and yield. Data were combined over 2010 and 2011 at Novelty, and at Portageville in 2010, liming rate, and P stabilizer except for silage dry weight.

\begin{tabular}{|c|c|c|c|c|}
\hline \multirow[b]{3}{*}{ P source $\mathrm{e}^{\dagger}$} & \multicolumn{2}{|c|}{ Silage dry weights } & \multirow{3}{*}{$\begin{array}{c}\text { Grain } \\
\text { moisture }^{\S}\end{array}$} & \multirow[b]{3}{*}{ Yield } \\
\hline & \multicolumn{2}{|c|}{ Liming rate } & & \\
\hline & None & Recommended & & \\
\hline & ------ & 4g ha ${ }^{-1}-\cdots$ & $\mathrm{g} \mathrm{kg}^{-1}$ & $\mathrm{Mg} \mathrm{ha}^{-1}$ \\
\hline Non-treated & 14.6 & 16.8 & 262 & 8.90 \\
\hline DAP & 15.3 & 16.2 & 253 & 9.10 \\
\hline TSP & 16.6 & 16.0 & 249 & 9.24 \\
\hline $\operatorname{LSD}(P=0.1)$ & ---- & -1.4------------- & 7 & 0.27 \\
\hline
\end{tabular}

${ }^{\dagger}$ DAP and TSP was applied at a $117 \mathrm{~kg} \mathrm{P}_{2} \mathrm{O}_{5} \mathrm{ha}^{-1}$ at Novelty in 2010, $112 \mathrm{~kg} \mathrm{P}_{2} \mathrm{O}_{5}$ ha $^{-1}$ at Novelty in 2011, and 56 $\mathrm{kg} \mathrm{P}_{2} \mathrm{O}_{5} \mathrm{ha}^{-1}$ at Portageville in 2010.

The recommended liming rate was $8.1 \mathrm{Mg} \mathrm{ha}^{-1}$ at Novelty $2010,3.4 \mathrm{Mg} \mathrm{ha}^{-1}$ at Novelty 2011 , and $4.5 \mathrm{Mg} \mathrm{ha}^{-1}$ at Portageville 2010.

${ }^{\S}$ Novelty location only

${ }^{\top} \mathrm{NS}=$ Not significant

\section{Conclusion}

The two P enhanced efficiency products did not consistently increase agronomic performance, including APRE, at the sites and under the environmental conditions or in interaction with several $\mathrm{P}$ fertilizers and liming practices evaluated in this research. Enhanced efficiency P products did not affect plant population, silage dry weight, grain moisture, yield, oil, protein, starch, or $\mathrm{N}$ uptake compared to the non-treated control. At Novelty, triple superphosphate treated with Avail ${ }^{\circledR}$ increased P uptake $8.6 \mathrm{~kg} \mathrm{ha}^{-1}$ compared to the non-treated control and 7.1 $\mathrm{kg} \mathrm{ha}^{-1}$ compared to $\mathrm{P}_{2} \mathrm{O}_{5}-\mathrm{Max}^{\circledR}$, but not at Portageville. Since in this trial the soils tested were acidic, additional research on the $\mathrm{P}$ enhancers performance in alkaline soils may be needed.

The application of lime resulted in mixed production results for the first year corn production after application, at the sites and environmental conditions in this research. Lime application decreased plant population 4800 plants $\mathrm{ha}^{-1}$ in 2011 at Novelty, and increased grain yields $0.77 \mathrm{Mg} \mathrm{ha}^{-1}$ at Portageville. Plant P uptake increased $3.4 \mathrm{~kg}$ $\mathrm{ha}^{-1}$ with the application of lime at Novelty, but was not affected at Portageville. This study showed no significant production differences between TSP and DAP at either location. The application of TSP increased grain yield $0.34 \mathrm{Mg} \mathrm{ha}^{-1}$ compared to the non-treated control, while no differences were observed between DAP and the no-treated control.

\section{References}

Barrow, N. J. (1984). Modelling the effects of pH on phosphate sorption by soils. J. Soil. Sci., 35, 283-297. http://dx.doi.org/10.1111/j.1365-2389.1984.tb00283.x

Bianchini, A. A., \& A. P. Mallarino. (2002). Soil-sampling alternatives and variable-rate liming for a soybean-corn rotation. Agronomy J., 94, 1355-1366. http://dx.doi.org/10.2134/agronj2002.1355 
Blevins, R. L., Murdock, L. W., \& Thomas, G. W. (1978). Effect of lime application on no-tillage and $\begin{array}{llllll}\text { conventionally tilled } & \text { corn. } & \text { Agronomy } & \text { 322-326. }\end{array}$ http://dx.doi.org/10.2134/agronj1978.00021962007000020025x

Bouldin, D. R, \& Sample, E. C. (1959). Laboratory and greenhouse studies with monocalcium, monoammonium, and diammonium phosphates. Soil Sci. Soc. Am. J. $25, \quad 338-342$ http://dx.doi.org/10.2136/sssaj1959.03615995002300050011x

Buchholz, D. D. (1992). Soil test interpretations and recommendations handbook. Dept. of Agronomy, University of Missouri, Columbia, MO.

Caires, E. F., Alleoni, L. R. F., Cambri, M. A., \& Barth, G. (2005). Surface application of lime for crop grain production under a no-till system. Agronomy J., 97, 791-798. http://dx.doi.org/10.2134/agronj2004.0207

Estes, G. O. (1972). Elemental composition of maize grown under no-till and conventional tillage. Agronomy J., 64, 733-735. http://dx.doi.org/10.2134/agronj1972.00021962006400060007x

García, M. C., Díez, J. A., Vallejo, A., García, L., \& Cartegena, M. C. (1997). Effect of applying soluble and coated phosphate fertilizers on phosphate availability in calcareous soils and on $\mathrm{P}$ absorption by a rye-grass crop. J. Agric. Food Chem., 45, 1931-1936. http://dx.doi.org/10.1021/jf960600a

Hu, Q., \& Buyanovsky, G. (2003). Climate effects on corn yield in Missouri. J. Applied Meteorology, 42, 1626-1635. http://dx.doi.org/10.1175/1520-0450(2003)042<1626:CEOCYI >2.0.CO;2

Karamanos, R. E., \& Puurveen, D. (2011). Evaluation of a polymer treatment as enhancer of phosphorus fertilizer efficiency in wheat. Can. J. Soil Sci., 91, 123-125. http://dx.doi.org/10.4141/cjss10071

Lim, K. L., \& Shen, T. C. (1978). Lime and P applications and their residual effects on corn yields. Agronomy J., 70, 927-932. http://dx.doi.org/10.2134/agronj1978.00021962007000060009x

Lu, D. Q., Chien, S. H., Henao, J., \& Sompongse, D. (1987). Evaluation of short-term efficiency of diammonium phosphate versus urea plus single superphosphate on calcareous soil. Agronomy J., 79, 896-900. http://dx.doi.org/10.2134/agronj1987.00021962007900050028x

Moschler, W. W., Martens, D. C., Rich, C. I., \& Shear, G. M. (1973). Comparative lime effects on continous no-tillage and conventionally tilled corn. Agronomy J., 65, 781-783. hhttp://dx.doi.org/10.2134/agronj1973.00021962006500050032x

Nathan, M., Stecker, J., \& Sun, Y. (2006). Soil testing in Missouri: A guide for conducting soil tests in Missouri. EC923. Missouri Cooperative Extension Service, Univ. of Missouri-Lincoln Univ., Columbia, MO.

Pavan, M. A., Bingham, F. T., \& Pratt, P. F. (1982). Toxicity of aluminum to coffee in Ultisols and Oxisols amended with $\mathrm{CaCO}_{3}$ and $\mathrm{CaSO}_{4}$. Soil. Sci. Soc. Am. J., 46, 1201-1207. http://dx.doi.org/10.2136/sssaj1982.03615995004600060017x

Reid, C. R., Winward, D. L., \& Koenig, R. T. (2004). A comparison of liquid phosphoric acid and dry phosphorus fertilizer sources for irrigated alfalfa production on calcareous soils. Comm. Soil Sci. Pl. Analysis, 35, 39-50. http://dx.doi.org/10.1081/CSS-120027633

Ritchey, K. D., Silva, S. E., \& Costa, V. F.. (1982). Calcium deficiency in clayey B horizons of savannah Oxisols. Soil Sci. Am. J., 133, 378-382. http://dx.doi.org/10.1097/00010694-198206000-00007

Rosen's Inc. (2012). P2O5-Max phosphate fertilizer additive for dry fertilizer impregnation. Retrieved from http://fs1.agrian.com/pdfs/P_Max_Label2.pdf

SFP. (2005). Material Safety Data Sheet. Specialty Fertilizer Products. Retrieved from http://www.chooseavail.com/WorkArea/showcontent.aspx?id=902

SFP. (2009). Science behind Avail ${ }^{\circledR}$. Specialty Fertilizer Products. Retrieved from http://www.chooseavail.com/Science.aspx

Ward, N. C. (2010). Impact of Avail ${ }^{\circledR}$ and Jumpstart ${ }^{\circledR}$ on yield and phosphorus response of corn and winter wheat in Kansas. M. S. thesis, K A Department of Agronomy, College of Agriculture, Kansas State University. pp. 1-116.

Woodruff, J. R., Moore, F. W., \& Musen, H. L. (1987). Potassium, boron, nitrogen, and lime effects on corn yield and earleaf nutrient concentrations. Agronomy J., 79, 520-524. http://dx.doi.org/10.2134/agronj1987.00021962007900030024x 